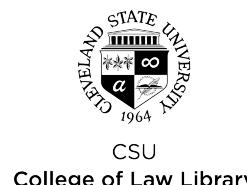

Cleveland State University

College of Law Library

\title{
EngagedScholarship@CSU
}

1997

\section{Lovewell v. Physicians Insurance Co.: Personal Liability for Prejudgment Interest}

Karin M. Mika

Cleveland State University, k.mika@csuohio.edu

Follow this and additional works at: https://engagedscholarship.csuohio.edu/fac_articles

Part of the Torts Commons

How does access to this work benefit you? Let us know!

\section{Original Citation}

Karin Mika, Lovewell v. Physicians Insurance Co.: Personal Liability for Prejudgment Interest, 45 Cleveland State Law Review 723 (1997)

This Article is brought to you for free and open access by the Faculty Scholarship at EngagedScholarship@CSU. It has been accepted for inclusion in Law Faculty Articles and Essays by an authorized administrator of EngagedScholarship@CSU. For more information, please contact research.services@law.csuohio.edu. 


\section{HEINONLINE}

Citation: 45 Clev. St. L. Rev. 7231997

Content downloaded/printed from

HeinOnline (http://heinonline.org)

Fri May 18 09:34:22 2012

-- Your use of this HeinOnline PDF indicates your acceptance of HeinOnline's Terms and Conditions of the license agreement available at http://heinonline.org/HOL/License

-- The search text of this PDF is generated from uncorrected OCR text. 


\title{
LOVEWELL v. PHYSICIANS INSURANCE CO.: PERSONAL LIABILITY FOR PREJUDGMENT INTEREST
}

\author{
KARIN MIKA ${ }^{1}$
}

On June 25, 1997, the Supreme Court of Ohio decided the case of Lovervell $v$. Physicians Insurance Co. ${ }^{2}$ In Lovetvell, the Ohio Supreme Court held that a physician who decided not to settle a malpractice claim brought against him could be made personally liable for any prejudgment in terest award made. ${ }^{3}$ This prejudgment interest award was made subsequent to a trial on the underlying malpractice action at which the physician was defended by the attorney for his insurer. ${ }^{4}$ The Ohio Supreme Court determined that personal liability for prejudgment interest could attach despite the physician's possessing an insurance contract that granted him the right to refuse settlement of a medical malpractice claim. 5

The decision in Lovervell presents a variety of intriguing issues and unanswered questions relating to insurance law. First, it may no longer be assumed that the insurer acts in tandem with the insured when the insurer is defending a suit brought against the covered individual. In fact, because of the Lovervell decision, insurers and their insureds may wind up with opposing interests during the course of litigation, even when they are theoretically on the same side. Secondly, the Lovervell decision seems to be contrary to one of the basic tenets of insurance law -that an insurance contract must be construed liberally in favor of the insured and strictly against the insurer.6 Because the contract in Lovetvell was construed strictly against the insured, there will be opportunity for insurers of all types to deny coverage for situations previously were to be anticipated to be covered under the contract. Third, the decision gives insureds cause to wonder whether a clause allowing them the right to refuse settlement may result in personal liability.

Insurers and insureds alike need to be aware of the Lovervell decision and its possible impact on current contractual relationships and on the negotiation of future insurance contracts. As important as what was stated in the opinion of the Ohio Supreme Court was what was not stated. The issues that were not

1B.A., Baldwin-Wallace College (1986); J.D., Cleveland-Marshall College of Law (1989). Assistant Director of Legal Writing, Research \& Advocacy at Cleveland-Marshall College of Law.

2679 N.E.2d 1119 (Ohio 1997).

3 Id. at 1121 .

4 Id. at 1120 .

5 Id. at 1121 .

${ }^{6}$ See, e.g., Miller v. Shelby Mut. Ins. Co., 253 N.E.2d 801 (Ohio 1969). 
addressed leave some previously settled concepts of insurance law wide open for interpretation in the future.

Facts:

In 1992, Plaintiff Frank Lovewell brought a medical malpractice action against Dr. Pradist Satayathum. ${ }^{7}$ Dr. Satayathum's insurer was the Physician's Insurance Company of Ohio. ${ }^{8} \mathrm{Dr}$. Satayathum's insurance contract with Physician's Insurance gave him the right to refuse a settlement with any individual bringing a medical malpractice action against him. ${ }^{9} \mathrm{Dr}$. Satayathum exercised this right and refused to settle the claim.10 The medical malpractice action went to trial. Eventually Dr. Satayathum was found liable for medical malpractice and the plaintiff was awarded damages in the amount of $\$ 200,000.11$ Thereafter, the plaintiff made a motion for prejudgment interest under section 1343.03(C) of the Ohio Revised Code alleging Dr. Satayathum had failed to make a good faith effort to settle the case. ${ }^{12}$ The trial court granted this motion. 13

Although Dr. Satayathum's insurance carrier paid the damage award assessed at trial, the carrier refused to pay the prejudgment interest.14 Physician's Insurance cited Dr. Satayathum's personal decision not to settle as the reason he should be held personally liable and the insurance company absolved from any liability under the policy. 15 The plaintiff, Frank Lovewell, commenced an action against both Dr. Satayathum and his insurance carrier to compel payment of the award.16 Dr. Satayathum cross-claimed against his carrier. ${ }^{17}$ The trial court found that the insurer, in fact, was obligated to pay the award under the policy. ${ }^{18}$ Summary Judgment was granted on behalf of both

${ }^{7}$ Lovewell v. Physicians Ins. Co., No. 68542, 1995 Ohio App. LEXIS 4606, at *3 (Cuyahoga Cty. Ct. App. Oct. 19, 1995).

8 Id. at ${ }^{*} 1$.

9679 N.E.2d at 1120 .

${ }^{10}$ Id.

111995 Ohio App. LEXIS 4606, at *3.

12 Id.

${ }^{13}$ Id.

14679 N.E.2d at 1120.

15 Id.

16 Id.

${ }^{17}$ Id.

${ }^{18}$ Id. 
Frank Lovewell and Dr. Satayathum. ${ }^{19}$ Physician's Insurance appealed this decision to the Eighth Circuit Court of Appeals.20

The Appellate Court Decision:

In affirming the lower court's decision, the Court of Appeals focused on two major points. The court first concluded that it was obligated to glean the intent of the contract "from the plain language of the policy and not the unexpressed intentions of the parties." 21 In doing so, the court focused on the insurance policy which provided coverage for "all sums, ... which [the insured] . . . legally become[s] obligated to pay as damages because of a medical incident." 22 Secondly, the court noted a long line of cases which characterized prejudgment interest as "compensatory" rather than "punitive." 23 Since the insurer conceded that it would be liable for compensatory damages under the contract, 24 the court held that the plain language of the contract covered "compensatory" prejudgment interest stemming from a medical incident. 25 The court also noted that since the insurer had given Dr. Satayathum the contractual right to refuse settlement, it could not refuse to pay the prejudgment interest award when the right was exercised. 26 The court held, in essence, that since Dr. Satayathum's right to refuse settlement was included in the express language of the contract, it was the insurer who legally refused a good faith effort to settle. 27

The Majority Opinion of the Ohio Supreme Court:

Chief Justice Thomas Moyer, writing for the majority, disagreed with the lower court's assessment that the "plain language" of the contract necessarily covered liability for prejudgment interest. 28 In fact, Moyer reached the opposite conclusion about the "plain language" of the contract. 29

19679 N.E.2d at 1120 .

201995 Ohio App. LEXIS 4606, at *3.

21 Id. at $* 7$.

22Id. (Emphasis added by the court.)

23Id. at ${ }^{* 8}$ (citing Galayda v. Lake Hosp. Sys., Inc., 644 N.E.2d 298 (Ohio 1994); Moskovitz v. Mt. Sinai Med. Ctr., 635 N.E.2d 331 (Ohio 1994); Digital \& Analog Design Corp. v. North Supply Co., 590 N.E.d 737 (Ohio 1992); Dailey v. Nationwide Demolition Derby, Inc., 480 N.E.2d 110 (Ohio Ct. App. 1984); Lawrence R.R. Co. v. Cobb, 35 Ohio St. $94(1878))$.

24 Id.

251995 Ohio App. LEXIS 4606, at *10.

26 Id. at *10-11.

27 Id. at ${ }^{*} 11$.

28679 N.E.2d at 1122 .

29 Id. 
In reaching his conclusion, Chief Justice Moyer first commented that since the question raised was one of contract interpretation, it was one to be resolved by the court. ${ }^{30} \mathrm{He}$ then addressed the purpose of section 1343.02 (C) of the Ohio Revised Code. Moyer stated that the statute was enacted to encourage settlement, prevent frivolous delays, and compensate a plaintiff "for the defendant's use of money which rightfully belonged to the plaintiff." $31 \mathrm{He}$ stated that the court had held in the past that the named defendant was "ultimately responsible for payment of a judgment rendered against her and for payment of any prejudgment interest thereon." $32 \mathrm{He}$ conceded, however, that the statute itself did not allocate the burden of payment between the tortfeasor and insurer. ${ }^{33}$

In referencing the insurance contract between Dr. Satayathum and his carrier, the court found that a medical incident was defined as "any act or omission in the furnishing of professional medical services." 34 The court disagreed with the argument that "but for" the original malpractice claim there could not have been a prejudgment interest award. Moyer noted that there were many other malpractice actions that resulted in a doctor's liability but did not result in an assessment of prejudgment interest. 35

Disagreeing with the lower court, Moyer stated that the contract clearly did not cover prejudgment interest because prejudgment interest was not specifically listed as being covered. ${ }^{36}$ The Chief Justice pointed out that postjudgment interest was expressly listed as covered within the contract and thus concluded there was a clear intent to include one and to exclude the other. ${ }^{37}$ While the Chief Justice agreed that prejudgment interest should be characterized as "compensatory" rather than "punitive," he concluded that even compensatory prejudgment interest would not fall under the definition of a damage stemming from a medical incident. ${ }^{38}$ Finally, Chief Justice Moyer

${ }^{30} \mathrm{Id}$. at 1121 (citing Alexander v. Buckeye Pipe Line Co., 374 N.E.2d 146 (Ohio 1978)).

31 Id. (citing Musisca v. Massillon Community Hosp., 635 N.E.2d 358, 360 (Ohio 1994)).

32 Id. (citing Peyko v. Frederick, 495 N.E.2d 918, 921 (Ohio 1986)).

33679 N.E.2d at 1121.

34 Id.

35 Id.

36 Id. at 1223.

${ }^{37} I d$. The court noted that there was a substantive difference between prejudgment and postjudgment interest. Id. The court noted that while prejudgment interest was an award given when a defendant lacked good faith in the settlement negotiations, postjudgment interest did not suggest bad faith. Id. Rather, it was an inducement for a defendant to pay an award promptly. Id. Moyer pointed out that an award of prejudgment interest required a hearing while an award of postjudgment interest did not. Id.

38679 N.E.2d at 1123. 
stated that it would be illogical for an insurer to be liable for failing to make a good faith attempt at settlement when it was the insured who chose not to settle. 39

\section{Other Opinions:}

Justice Cook concurred in the opinion of the majority but approached her decision with a different analysis. 40 Cook stated that the first inquiry was to determine who was liable to the original plaintiff for prejudgment interest. 41 The justice concluded that $\mathrm{Dr}$. Satayathum was the only individual liable under the statute and that the statutory allocation of the award to the insurer was not at issue unless the insurance contract covered the award. 42

Justice Cook then examined the plain language of the contract and determined that it could not be read to cover prejudgment interest. ${ }^{43}$ Although the justice agreed with the majority's assessment that prejudgment interest was not a damage that stemmed from a medical incident, she believed the majority put too much emphasis on the potential that such a damage could possibly be impliedly covered. ${ }^{44}$ In conclusion, Justice Cook stated that there was no real issue of fault with respect to liability. The justice commented that, "[W]hether the failure to settle in good faith was the fault of the doctor or the insurance company is only important if the policy language turns on fault." 45

The remaining justices were split in their decisions. Justices Pfeifer, Lundberg, and Stratton concurred with the majority. ${ }^{46}$ Justice Douglas dissented. 47 Justices Resnick and Sweeney dissented and would have affirmed the court of appeals. 48

Analysis:

The Supreme Court of Ohio and the Eighth District Court of Appeals reached opposite conclusions regarding personal liability for prejudgment interest, but each did so reading "clear and unambiguous" language to mean different

${ }^{39} \mathrm{Id}$. at 1124.

40 Id.

41 Id.

42 Id.

43679 N.E.2d at 1124.

44 ld. at 1125.

45 Id.

$46 I d$. at 1124.

${ }^{47}$ Id.

48679 N.E.2d at 1124 
things. ${ }^{49}$ In doing so, the courts have left open the question as to what basic tenets of insurance contract interpretation should be applied in the future in these situations. Moreover, neither court fully addressed the nature of the fiduciary and legal relationship between the insured and the insurer. Since the Ohio Supreme Court did not deal with this issue, numerous questions about what will now be the ethical obligations between an insured and an insurer where legal representation is concerned are left open.

Although both the court of appeals and the Ohio Supreme Court focused their attention on the basic principle that terms of a contract, where unambiguous, should be enforced and given their plain meaning, 50 neither deals with another basic tenet of contract construction: ambiguous provisions in an insurance contract should be liberally construed in favor of the insured and against the insurer. ${ }^{51}$ While it is certainly logical to posit that a tenet for interpreting ambiguous provisions should not be invoked when the provisions are unambiguous, it would appear that there is a fair amount of ambiguity if two different courts find that, after examining "unambiguous" provisions, the contract "clearly" says different things.

It is impossible to speculate whether the Ohio Supreme Court would have reached the same conclusion were they to have found ambiguity in the contract. On the one hand, liberal interpretation in favor of Dr. Satayathum might have lead to a finding that the contract covered prejudgment interest (as the court of appeals found). On the other hand, such a finding would have been contradictory to the court's opinion that the blameworthy party should be the individual liable for the prejudgment interest. 52 One thing is certain, by the court's decision in Lovezvell, a change was made in the traditional legal understanding that role of the insurer in litigation as being the representative and protector of the interests of the insured.53

The relationship between an insurer and an insured has traditionally been one of a virtual synonymous identity between the two entities.54 This is primarily because of the unequal bargaining powers between the two 55 that enables the insurer to control the insured's monetary fate.56 Even in Peyko $v$.

49 Id. at 1122; 1995 Ohio App. LEXIS 4606, at *7.

50679 N.E.2d at 1122; 1995 Ohio App. LEXIS 4606, at *7.

51 The Ohio Supreme Court mentioned this rule of contract interpretation but determined that no ambiguity existed that would require its application. 679 N.E. $2 \mathrm{~d}$ at 1122.

52 Id. at 1124 .

53 See generally, Douglas R. Richmond, Insured's Bad Faith as Shield or Stword: Litigation Relief for Insurers?, 77 MARQ. L. REv. 41 (1993).

54 Id. at 42.

55 Id.

56 Id. at 44 . 
Frederick, 57 which the Ohio Supreme Court cited to support the premise that the "responsible party" is ultimately responsible for paying prejudgment interest, the court found that a responsible party could not hide behind the mistaken premise that the identity of the insurer and the insured were separable. ${ }^{58}$ This inseparability stems from many features that exist in the relationship between the insured and the insurer. These are not unlike the relationship between master and servant. Insurance contracts generally impose the obligation of defense upon the insurer. ${ }^{59} \mathrm{By}$ the same token, the insurer may invoke any defenses the insured may have in the action. 60

In the case of Lovezvell, Defendant Dr. Satayathum had a standard contract obligating his insurer to defend him in a medical malpractice action; 61 however, Dr. Satayathum's contract also contained a clause that allowed him to have final say over any settlement.62 There was no other clause explaining the potential repercussions of refusing a settlement and what would transpire with respect to the legal relationship he had with the insurer should he invoke this contractual option. The court of appeals noted this lack of specificity with the contract and stated that if the insurer wanted to "place the risk of withholding consent to settlement on the insured, it could have done so in plain language in the policy." 63

The Ohio Supreme Court did not address this issue in its opinion. Granted, in doing so, the court may have suggested that there was ambiguity within the contract; however, in failing to address this issue, the court left the door open for future conflicts of interpretation. Since it is now likely that litigation will arise as to whether an insured or an insurer will be responsible for paying a prejudgment interest award, future courts will have to decide the significance of "right to refuse settlement" clauses, and whether contracts containing such clauses should also include an additional provision that clearly spells out the personal monetary risk to the insured. Such a determination would comport with general principles of insurance law that favor construction of insurance contracts liberally for the insured and strictly against the insurer. ${ }^{64}$ Moreover, this determination would serve a fairness aspect since it is likely that contracts

57495 N.E.2d 918 (Ohio 1986).

58Id. at $920-21$.

59 See, e.g., Sanderson v. Ohio Edison Co., 635 N.E.2d 19 (Ohio 1994); Motorists Mut. Ins. Co. v. Trainor, 294 N.E.2d 874 (Ohio 1973).

${ }^{60}$ See generally, Michael F. Flynn, Private Medical Insurance and the Collateral Source Rule: A Good Bet?, 22 U. TOL. L. Rev. 39 (1990).

611995 Ohio App. LEXIS 4606, at *3.

62679 N.E.2d at 1120.

631995 Ohio App. LEXIS 4606, at *11 (citing Karabin v. State Auto. Mut. Ins. Co., 462 N.E.2d 403 (Ohio 1984)).

64 See Miller v. Shelby Mut. Ins. Co., 253 N.E.2d 801 (Ohio 1969). 
containing a "right to refuse settlement" clause are likely acquired at a higher premium than are contracts not granting such a right.

The Ohio Supreme Court's failure to discuss the repercussions of a missing diclaimer of liability will likely result in future litigation dealing with conflicts of interest between an insured and his insurer. In the case of a malpractice action, an attorney for the insurer could be pitted against the insured when issues of bad faith arise. In that situation, the insured would not only be left without legal representation, but would be left on his own against the word of his insurer. Any counsel that would be retained subsequent to a conflict about liability for prejudgment interest would not have been part of the proceedings that lead to the dispute. Furthermore, the insured might actually wind up in a situation where he was not present at the proceedings where his personal fault (bad faith) was determined.

Since the insurer and the insured will always be in a potentially adversarial relationship whenever a "right of settlement" clause exists, there would be a potential conflict of interest throughout every phase of a proceeding. An insured who is not an attorney may not be aware that exercising his contractual right may wind up making him personally liable for any part of the judgment. There would additionally be an incentive for the insurer to minimize any part it may have in a failure to settle, even if the position of the insurer is the same as the insured respecting settlement. Frankly, some settlements might be discouraged because the insurer would be aware throughout the proceedings that if it is the insured who makes that choice under the contract, the insurer may not be liable. It may be worth it for the insurance company to gamble on litigation.

Furthermore, Lovezvell somewhat confuses the premise that prejudgment interest is to be regarded as compensatory rather than punitive. 65 While the Ohio Supreme Court reiterated that prejudgment interest was to be regarded as compensatory, but was not necessarily compensation stemming from a medical incident, 66 Dr. Satayathum was, in fact, penalized for exercising a contractual right. While O.R.C. 1343.03(C) makes sense in the context that prejudgment interest should be awarded if a legal representative would fail to make a good faith effort to settle a case, imposing a legal standard of good faith on a non-attorney would do no more than penalize a non-attorney for invoking his or her right under the contract.

Lovervell adds a new dimension to insurance law. Individuals who have contracts giving them final right over settlement should be concerned that exercising such a right may result in personal liability. These same individuals should be concerned about a potential conflict of interest that may occur when being defended by the insurer. Lovetvell seems to make necessary that an

65 See Musisca v. Massilon Community Hosp., 635 N.E.2d 358 (Ohio 1994).

66679 N.E.2d at 1123 (citing Galayda v. Lake Hosp. Sys., Inc., 644 N.E.2d 298 (Ohio 1994)). 
insured should retain separate counsel to protect his interests in case a potential conflict of interest develops with the insurer.

With respect to the contracts themselves, insurers would serve themselves well by making sure the inclusion of a clause giving right to refuse a settlement includes with it a clause stating that personal liability may result from exercising such right. In counseling insureds about settlement, it should be incumbent upon the attorney for the insurer to make sure that the insured knows that exercising the right may result in personal liability. When an insured is not an attorney, his or her decision not to settle may be a decision out of principle, but may also be legally ill-advised. The insured must be apprised of the resulting risk. This could avoid any future suits against the insurance company for its legal representation.

\section{Conclusion:}

The Ohio Supreme Court's decision in Lovetvell raises many issues regarding the future of litigation involving parties who refuse to settle pursuant to a contractual right. Although, on the surface, it would appear that the court clarified what entity would ultimately be responsible for paying a prejudgment interest award, its failure to address other issues left open the potential for future litigation concerning the traditional relationship between the insurer and the insured. While Lovetvell does not necessarily mean the death knell for "right to refuse settlement" clauses, both insurers and insureds need to be made aware of the potential risks of having a contract that includes such a clause. 
HeinOnline -- 45 Clev. St. L. Rev. 7321997 